\title{
「しんかい6500」に搭載されたサブボトムプロファイラを用いた マリアナトラフ背弧拡大軸付近の表層堆積物観察
}

\author{
小池 悠已 ${ }^{1 *}$ ， 富士原 敏也 ${ }^{2} ， \quad$ 海野 進 $^{3} ， \quad$ 浅田 美穂 4 ，岡田 聡 5
}

マリアナトラフ背弧拡大軸 $17^{\circ} \mathrm{N}$ 付近では, 枕状溶岩とシート状溶岩の 2 種が分布して扔り，それぞれ拡大軸谷端，中央に 分布している．これらは，溶岩噴出量の違いを示唆しているとともに，形成年代の変化も示している可能性がある. 本稿で は, YK08-08 Leg.1航海で行われた，「しんかい6500」に搭載したサブボトムプロファイラの観測結果を報告する. 行われた3 潜航（拡大軸西側斜面でのDive \#1088と\#1090，拡大軸東側斜面での\#1089）のSBPデータと潜水船外写真を照らし合わせ，表 層堆積物を観測した，その結果，\#1088は，表層堆積物をほとんど認識できないことから，新しい溶岩流であることが推定で きた. \#1089は, 堆積層厚も明瞭に観測され, 堆積層中に基盤面と平行な反射面も識別できた。 \#1090では, 各地点の目視観 察で堆積物の被覆を認識できたが，SBPでは堆積層厚を識別できなかった．したがって\#1089の斜面より堆積層が薄いと考え られる.これら3潜航測線下の溶岩流は\#1089, \#1090, \#1088付近の順に形成された可能性がある.

キーワード : マリアナトラフ背弧拡大軸, 表層堆積物, サブボトムプロファイラ, しんかい6500

2008年7月24日受領 ; 2008年9月30日受理

1 高知大学大学院理学研究科

2 海洋研究開発機構地球内部変動研究センター

3 金沢大学自然システム学系

4 東京大学海洋研究所

5 日本海洋事業

代表執筆者：

小池 悠已

高知大学大学院理学研究科自然環境科学専攻 / JAMSTEC: IFREE1研究生

T237-0061 神奈川県横須賀市夏島2-15

+81-46-867-9313

koikey@jamstec.go.jp

著作権: 独立行政法人海洋研究開発機構 


\title{
- Report -
}

\section{Observation of sediments in a back-arc basin spreading center of the Mariana Trough using a subbottom profiler installed on the Shinkai 6500}

\author{
Yuki Koike ${ }^{*}$, Toshiya Fujiwara ${ }^{2}$, Susumu Umino ${ }^{3}$, Miho Asada ${ }^{4}$, Satoshi Okada ${ }^{5}$
}

Both pillow and sheet lava flows are distributed in the Mariana Trough back-arc basin axis at $17^{\circ} \mathrm{N}$. These flows suggest different eruption rates, and they may indicate age variation in the lava. In this report we present observational results of sediments using a subbottom profiler (SBP) installed on the Shinkai 6500 during the YK08-08 Leg1 cruise. Observations from three dives (\#1088 and \#1089 on the western slope, \#1090 on the eastern slope) with the SBP with visual observations and camera photos taken by the Shinkai 6500 were conducted to observe sediment on the lava flows. We estimate that the lava flow is new in dive \#1088 because the SBP and visual observation cannot find sediment cover. In dive \#1089 the sedimentary layer can be observed distinctly; moreover we can find a reflection within the sedimentary layer parallel to the basement. In dive \#1090 we can find sediment cover by visual observation, but cannot determine sediment thickness by SBP observation. We consider the sediment coating in the dive \#1090 survey area to be thinner than that in dive \#1089. Therefore, it is possible to consider that these lava flows formed in the order \#1089, \#1090, and \#1088.

Keywords : Mariana Trough, sediment, sub-bottom profiler, Shinkai 6500

Received 24 July 2008 ; accepted 30 September 2008

1 Department of science, Kochi university

2 Institute for Research on Earth Evolution(IFREE), Japan Agency for Marine-Earth Science and Technology(JAMSTEC)

3 School of natural System, Kanazawa University

4 Ocean Research Institute, University of Tokyo

5 Marine Science Department, Nippon Marine Enterprises

Corresponding author:

Yuki Koike

Kochi university / Institute for Research on Earth Evolution(IFREE), Japan Agency for Marine-Earth Science and Technology(JAMSTEC)

2-15, Natsushima, Yokosuka, 237-0061, Japan

$+81-46-867-9313$

koikey@jamstec.go.jp

Copyright by Japan Agency for Marine-Earth Science and Technology 


\section{1. はじめに}

背弧海盆に抒ける海底拡大に関する研究は, 背弧下 ウェッジマントル内でのマントル対流, 背弧と島弧で生成 されるマグマが相互作用する複合系の海洋リソスフェア形 成を解明するのに重要である，ウェッジマントルでは，海 洋プレート沈み込みによる強制流動とマントル深部からの

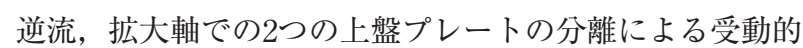
流が複合したマントル対流が起こっている．背弧海盆は弧 状に拡大していることから，マントル対流のジオメトリー が時間的，空間的に変化することが考えられる。 また，そ れらに連動して背弧海盆下のマグマソースが変化すること も考えられる。

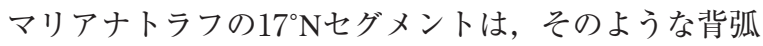

海盆拡大の特徵が現れている場所かもしれない（Fig.1）. 中部マリアナトラフの背弧海盆拡大軸谷内で行われた深 海曳航サイドスキャンソナーを用いた海底調査では, $17^{\circ} \mathrm{N}$ のセグメントでは滑らかな海底表面を推定させる 後方散乱パターンと凸凹した表面を推定させるパターン の2パターンが確認された（Deschamps et al., 2005; Asada et al., 2007).これら滑らかなパターン, 凸凹なパターン はそれぞれシート状溶岩流, 枕状溶岩流と推定され，マ リアナトラフは両側 $3 \mathrm{~cm} / \mathrm{yr}$ という低速拡大であるにもか かわらず，噴出率が高いことを示唆するシート状溶岩が 分布している.

地震波速度構造の結果からは，17ํセグメント拡大軸 付近の約 $30 \mathrm{~km}$ の範囲で, トラフ内の平均より約 $2 \mathrm{~km}$ 地殼

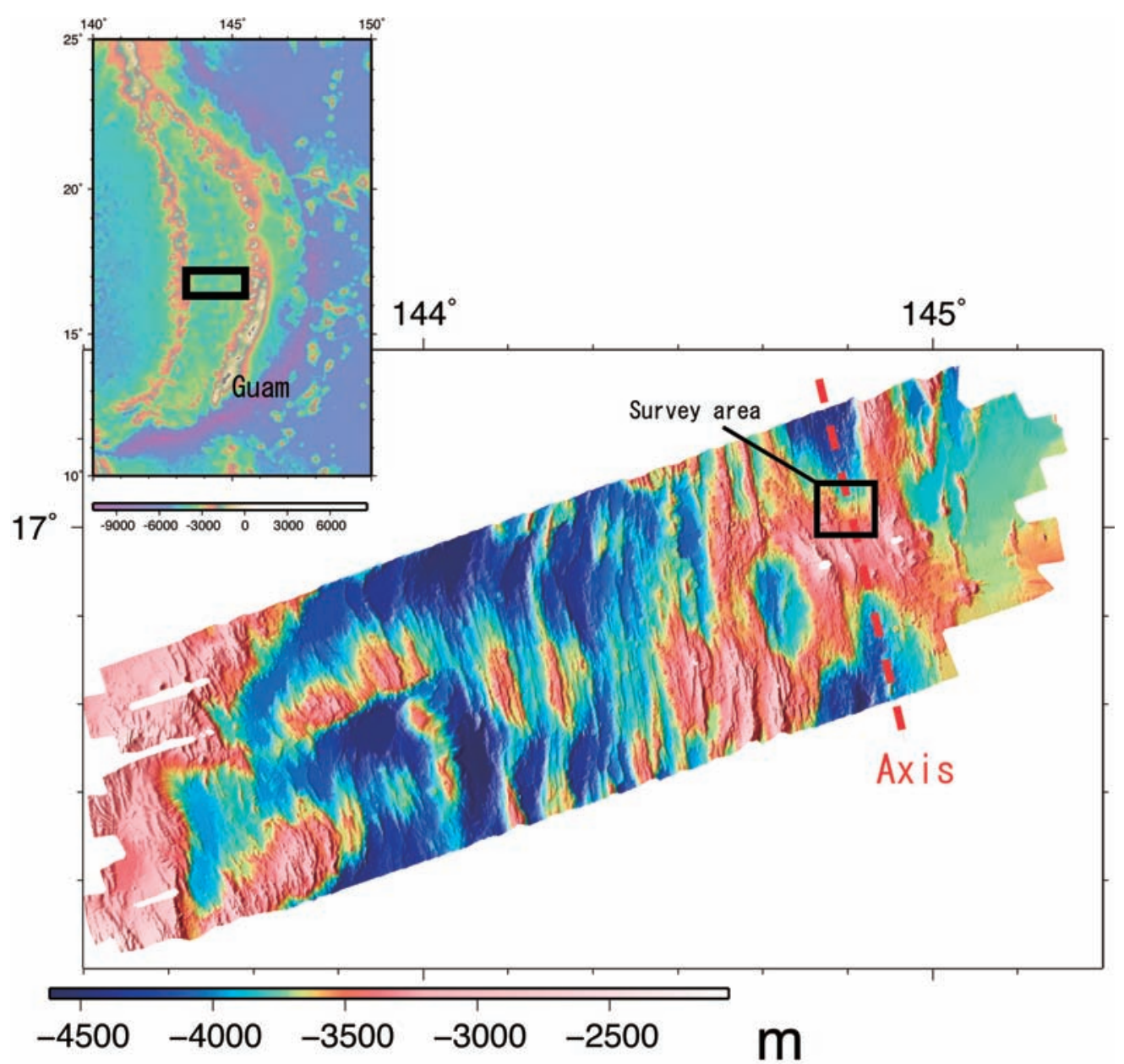

Fig. 1 Bathymetry acquired on this cruise around $144^{\circ} \mathrm{E}, 17^{\circ} \mathrm{N}$.

The inset shows the Mariana Trough. The black square in the inset indicates the study area. The bathymetry data are gridded at 0.05 -minute intervals. The black square on the map shows the dive survey area. The red dotted line indicates the approximate location of the spreading axis.

図 1 本航海で取得した $144^{\circ} \mathrm{E}, 17^{\circ} \mathrm{N}$ 付近の海底地形

上図：マリアナ諸島全体を示し, 四角部分は本航海で得られた海底地形 (下図). etopo2から作成 下図：四角部分が潜航ポイント周辺を示す (Fig.4参照)。0.05分間隔でグリッドデータを作成 
が厚くなっていることがわかった（Takahashi et al., 2007; 2008)．厚い地殸の存在は，過分にマグマが供給されてい

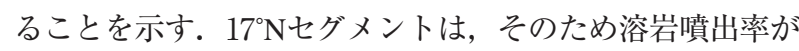
高いと整合的に解釈をすることができる．そして地殼厚異 常の範囲は，およそ 1 myrの期間（ $30 \mathrm{~km} \div 3 \mathrm{~cm} / \mathrm{yr}=1 \mathrm{myr} ）$ だけ，マグマ生産量が増大したものと解釈することができ るかもしれない.またサイドスキャンソナーでの観測に見 られるシート状溶岩流から枕状溶岩流への変化も，溶岩噴 出率の高低を示しており，時間変化を示唆している可能性 がある。

溶岩流噴出の時間的変化を知るためには，形成年代を 知ることが必要である，海底年代を知る方法は，岩石の年 代測定, 表層堆積物中の微化石による年代推測，堆積層厚 による相対年代などが挙げられる，本稿では溶岩流上に堆 積した堆積層厚を観測し，その厚薄から溶岩流の新旧を推 定した．絶対年代を求めることは難しいが，相対年代を求 めることで局所的な溶岩流の年代を理解し, 形成順序や各 年代による噴出量変化がわかるかもしれない.

調査船「よこすか」YK08-08 Leg1航海（2008年6月～7月） では，有人潜水調查船「しんかい6500」を用いて，合計6 潜航が行われ，マリアナトラフ背弧拡大軸 $17^{\circ} \mathrm{N}$ 付近では3 潜航（\#1088，\#1089，\#1090）で岩石採集と目視観察，物 理探査が行われた(Fig.4)。目視観測の結果については Fujiwara et al. (2008, 本号)を参照されたい. 本稿では，「し んかい6500」に取り付けたサブボトムプロファイラ（SBP） から求めた堆積層厚について報告する。溶岩流形成後，年 代が古いほど堆積層厚は厚くなることが考えられるため, SBPでの調査目標は堆積層厚を測り, その変化から相対的 な年代を推定することである。これらは溶岩流の新旧を判 別するため，重要な情報であると考えられる。

\section{2. 手法}

\section{1 サブボトムプロファイラ（StrataBox）}

サブボトムプロファイラは，音波を発信し，その反射 の強弱を識別し海底下の層状構造を認識する装置である. 本航海で使用したSBPは潜水船内のStrataBox本体と表示・ 収録を行うノートPC, 潜水船外の深海用トランスデュー サで構成されており, 浅海用の地層探査機のトランス デューサを深海用のものに交換している．本体電源は電池 ボックスを使用し $12 \mathrm{~V} ，$ トランスデューサの使用周波数は $10 \mathrm{kHz}$ で地質分解能は約 $6 \mathrm{~cm}$, 海底面から求めることがで きる最大探査深度は $40 \mathrm{~m}$ である（Table.1）。深海用のトラ ンスデューサに取り替えたことで，深海底の堆積層厚観測 を可能にしたが，潜水船に取り付けるため，海底から近い と送信音圧の強さと多重反射が強く重なるため，地層との
判別が困難となることから高度 $2.5 \mathrm{~m}$ 以上から観測する必要 がある。

2.2 YK08-08 Leg1航海におけるサブボトムプロファイラ 設置と設定，計測

本航海では，「よこすか」YK05-16 Leg1航海(Kumagai, 2005）と同様「「しんかい6500」のマニュピレータ下の 荷台にトランスデューサを取り付けた（Fig.2）。 YK0808 Leg1航海では, 潜航直前に電池ボックスとデータ保 存・モニターするノートPCを潜水船内に設置後, 起 動・収録テストを行い，一旦停止した。そして，潜水船 が着水準備に入り，吊り上げられると同時に起動・収録 を再び開始し，そのまま継続して海底の観測を行った。 本来なら，海底で起動・収録を行うことが好ましいが, 本航海では潜水中での不具合をなくすため, 潜水船外か らSBPの起動を確認できるように離船時に起動・収録を 開始した。海底観測終了時（離底時）にSBPの動作・収 録を停止し, 潜水船揚収後, ノートPCと電池ボックス の回収, データの吸出しと電池の交換を行った.

対象海域は堆積層が薄く，溶岩の基盤が露出している ことが予想されたので，基盤からの強い反射でSBPデー 夕上の地下浅部の微細な構造をつぶしてしまわないよ う, Range : 10mと短く, DC Gain：15dbと小さめに設定 した.

取得できたSBP生データをStrataBox付属ソフトで再 生，100～200秒毎に画面キャプチャし，イベントリスト， $\log$ ファイル等を用いて, 船外写真とSBPデータの場所と

Table. 1. Specifications of SBP (Strata Box) installed on the Shinkai 6500. Referenced from Kumagai (2005).

表 1 「しんかい6500」に搭載したSBP（Strata Box）のスペック概要 Kumagai 2005を引用

\begin{tabular}{|l|l|}
\hline $\begin{array}{l}\text { Recording Depth } \\
\text { Range }\end{array}$ & $5,10,20,40,80,150 \mathrm{~m}$ \\
\hline Resolution & $6 \mathrm{~cm}$ \\
\hline Penetration & $40 \mathrm{~m}$ \\
\hline Depth Accuracy & $0.5 \%$ \\
\hline Operation height & $2.5 \mathrm{~m}$ \\
\hline Sending rate & Max 10Hz \\
\hline Date File Output & ODEC format \\
\hline Frequency Output & $10 \mathrm{kHz}$ \\
\hline $\begin{array}{l}\text { Transmit Output } \\
\text { Power }\end{array}$ & $300 \mathrm{~W}$ (Pulsed) \\
\hline Input Power & $12 \mathrm{~V} \mathrm{DC,} \mathrm{Nominal} \mathrm{power} \mathrm{8W}$ \\
\hline
\end{tabular}




\section{「Shinkai 6500」}

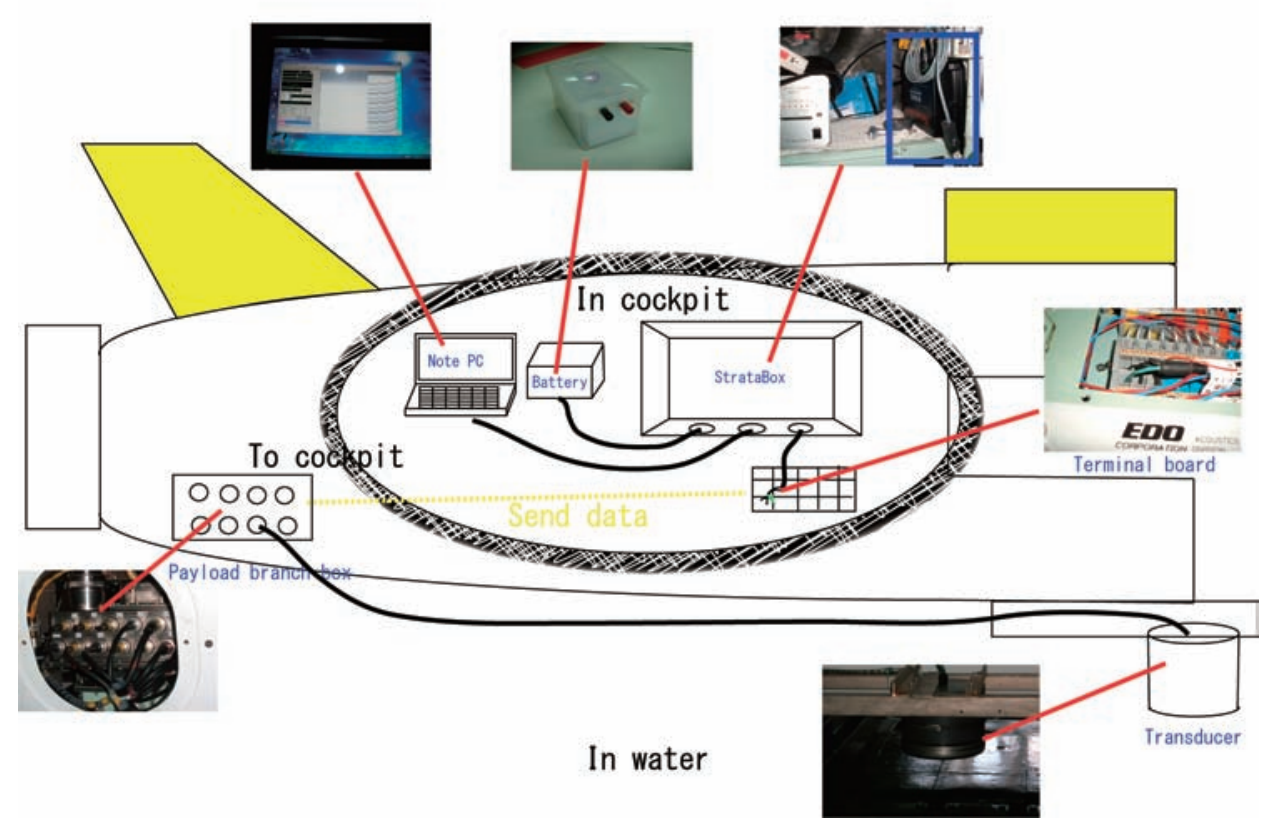

Fig. 2 Schematic figure of the SBP installed on the Shinkai 6500.

A transducer was mounted on a frame under the manipulators, and a transducer cable was connected to a payload branch box. In the cockpit, the StrataBox was connected to a terminal board, a battery, and a note book PC.

\section{図 2 しんかい6500によるSBP観測概念図}

トランスデューサは潜水船外のマニュピレータ下に荷台をつけ設置し，トランスデューサケーブルを「しんかい」 ペイロード分岐箱に接続した，船内では，StrataBox本体と「しんかい」ターミナルボード，電池ボックス，ノート PCを接続した。

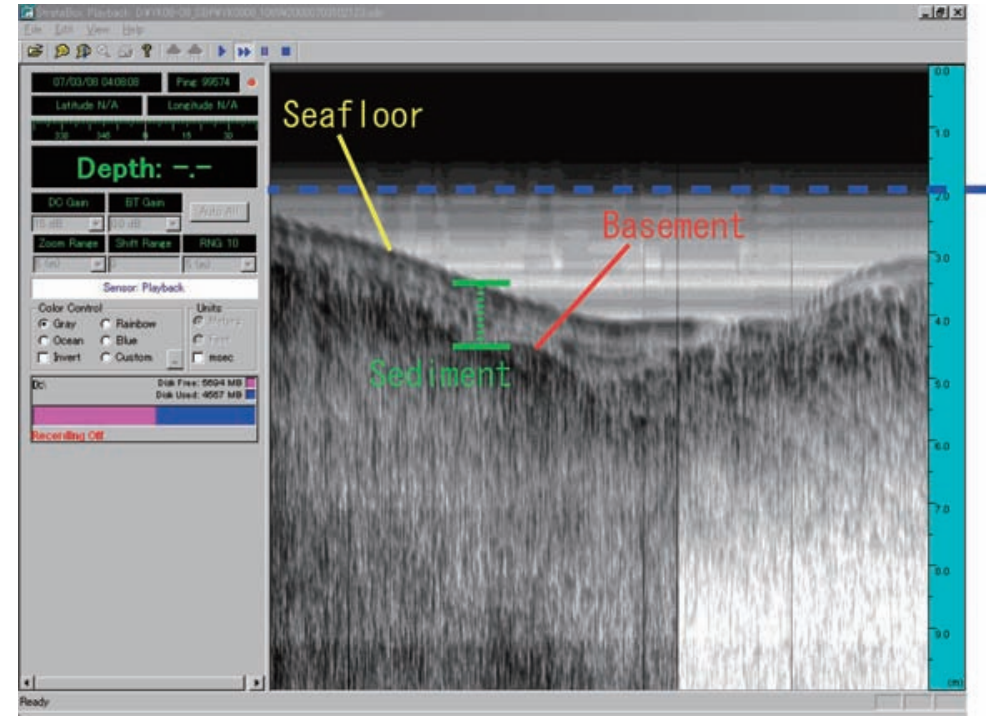

Fig. 3 Example of SBP data

The full range of the vertical axis is $10 \mathrm{~m}$, tick marks represent $0.5 \mathrm{~m}$. The full range of the horizontal axis indicates time of approximately one minute. Time is indicated in UTC, thus 10 hours can be added to translate to Guam time. As indicated by the blue dashed line, it is impossible to find reflections from geological structures at a depth of less than $2 \mathrm{~m}$. A one-meter-thick sedimentary layer is found at this site.

$$
\text { 図 } 3 \text { SBPデータ表示例 }
$$

縦軸は1メモリ $0.5 \mathrm{~m}$ 間隔で $10 \mathrm{~m}$ 表示しており，横軸は約1分間のデータを示す．時間はUTで表示されており，+10時間 でグアム時間となる．青破線で示すように， $2 \mathrm{~m}$ 以浅は海底面の識別が不可能であることがわかる．この地点では約 $1 \mathrm{~m}$ の堆積層が識別できる。 
時刻を合わせ，堆積層の厚さをStrataBoxで表示されてい るメモリから読み取り，3潜航の堆積層厚分布の推定を 行った (Fig.3).

\section{3. 結果・考察}

\#1088では，拡大軸谷中央から西へ向かう測線を取った (Figs.4,5)，潜水船外カメラでの写真では，表層堆積物に覆 われておらず，基盤を目視できた地点が多く（Fig.6b）， SBPデー夕は基盤による強い反射(Fig.6a 13:38)を示してい た。またSBPデー夕から海底面が識別できない地点も多数 あり (Fig.6c)，堆積層厚分布は確認することができなかっ た(Fig.9, Table.2). 本潜航の測線下では, 表層堆積物はSBP データから識別できず，写真でもほとんど認識されなかっ たことから，非常に新しい溶岩流である可能性が高い。

＃1089は，拡大軸谷東側斜面を南下し，火山性海丘を東 から西へ横断する測線(Figs 4,5)をとり，堆積層厚分布が唯 一明暸に推定することができた潜航である (Fig.9, Table.2). 潜航開始地点付近では堆積層を見ることはできなかった (Fig.7a 12:16)が，南下するにしたがって，拡大軸谷東側斜 面では堆積層が識別された(Fig.7b).測線上の潜航開始地 点の南側から火山性海丘の東側では，試料サンプリングポ イント付近では明膫なSBPデータが取れなかったが，堆積 層が1m以上あり(Fig.7a 14:27), 海丘頂上付近では, 堆積層 は薄くなっていた(Fig.7a 14:57). 行われた 3 潜航中, 最も 堆積層が明膫であった潜航であり, 堆積層中に平行なもう 一つの反射面を見ることもできた（Fig.7c）.

\#1090では, 潜航開始地点から拡大軸中央付近を南下し, そして拡大軸谷西側斜面を東から西に向かう測線を取った (Figs.4,5). 各地点の目視観察で堆積物を認識できる地点が 多数あるが，SBPデータでは層厚が識別できなかった。こ れは複雑地形の影響でSBPデータが明瞭ではないことが原 因と考えられる。また，起伏の大きい溶岩基盤の多方面反 射でSBPデータの散乱や回折がみられた(Fig.8b). Fig.8cで は，船外写真からなだらかな地形と表層堆積物が認識でき たが，SBPデータでは基盤面-海底面境界が明膫ではなく， SBPでは識別できないと判断した．SBPデータから数值に よる堆積層厚分布を推定することはできなかった (Fig.9,Table2).

各潜航を行った場所の海底は, 最も堆積層が厚かった \#1089，目視観察では確認できたが，SBPでは層厚が識別 できなかった\#1090, 溶岩の基盤が目視観察できるほど堆 積物が少なかった\#1088の順に形成されたことが推定され る. 北マリアナトラフでは, 堆積速度は〜 $2 \mathrm{~cm} / \mathrm{kyr}$ と推定 されている (海洋研究開発機構・金松敏也博士私信). $17^{\circ} \mathrm{N}$ リアナトラフも類似する堆積速度と仮定すれば,
0.5 2mの堆積層厚を識別できた\#1089は約10万年前に形成 され，0.5m以下の堆積層厚が識別できた\#1090は約 2.5 万年 前に形成，堆積層を認識できなかった地点が多かった\# 1088は2.5万年前より新しく形成されたことが推定される. マリアナトラフの海底拡大速度は片側約 $1.5 \mathrm{~cm} / \mathrm{yr}$ であるこ とから，単純に拡大軸中心からの距離により年代を換算す ると0〜40万年前に形成された海底と考えられるが，潜航 で識別できた堆積層から推定する海底はそれより若い. Neo-volcanic Zoneは広く，拡大軸谷内の範囲で溶岩噴火が 起こると考えられる。 \#1089でみられた2重の堆積層 （Fig.7c）は，時間間隔を置いて軸谷内で起こる割れ目噴火 により, 半遠洋性堆積層上に火山砕屑物が堆積したことを 示唆しているかもしれない. 採取した岩石サンプルのK-Ar やAr-Ar放射年代測定には年代が新しすぎる可能性があり， 堆積物サンプル中の微化石は, 現世化石であることを示す のみで, 詳細な年代変化の把握はSBPが有力な情報である. 本航海の3潜航でこれだけの情報が得られたが，より多く の測線を得て, 広範囲で深海堆積層厚デー夕を収集し, 解 析することで，拡大軸谷内での噴火イベントの有無や相対 的な海底形成順序, 海洋地凯形成過程を詳細に知ることが できるだろう。

本航海でのSBP観測から，行われた3潜航の測線下での 表層堆積物の観測は成功し，その有無が推測できた。しか し, SBPデー夕と船外写真が明膫ではない地点が多数確認 された。この主な原因は2つ挙げられる.

つめは，目視観察とSBP観測の最適な観測環境の違い である．Figs.6a,7a,8aなどでみられるように，写真で海底が 明瞭であった場合, SBPデータでは海底面を識別が困難で あり，SBPデー夕から海底面が識別しやすい場合，写真で は海底が明瞭ではないことがある（Fig.7a 14:34）。これは 目視観察では船体〜海底の高度1〜2mが適していることに 対し，SBPでは高度 $2.5 \mathrm{~m}$ 以上での観測が適しているためで ある。そのため, 高度 $0 \mathrm{~m}$ をる試料サンプリング中は, 海底面を識別できないが，サンプリングポイント間を移動 する際のSBPデータでは海底面の推測が可能であり, 物理 探査を主な目的とせずとも，SBPデー夕から堆積層厚の識 別が可能である.

2つめは対象海域の底質, 地形など海底の地質環境であ る. 本航海では, SBPデータでは堆積層が識別されない地 点でも写真やプッシュコアでの表層堆積物採取から表層堆 積物の厚さが $0.2 \sim 0.3 \mathrm{~m}$ ぼあると報告され，StrataBox 久 ペックの解像度である $6 \mathrm{~cm}$ オーダーの微細構造を識別でき ず， $0.5 \mathrm{~m}$ 以下の堆積層厚では詳細な数值による識別は困難 であった，そのため，本航海では $0.5 \mathrm{~m}$ 以， $0.5 \mathrm{~m} \sim 1 \mathrm{~m}$, $1 \mathrm{~m}$ 以上と三つに分けた。しかし，本航海で行った観測と 


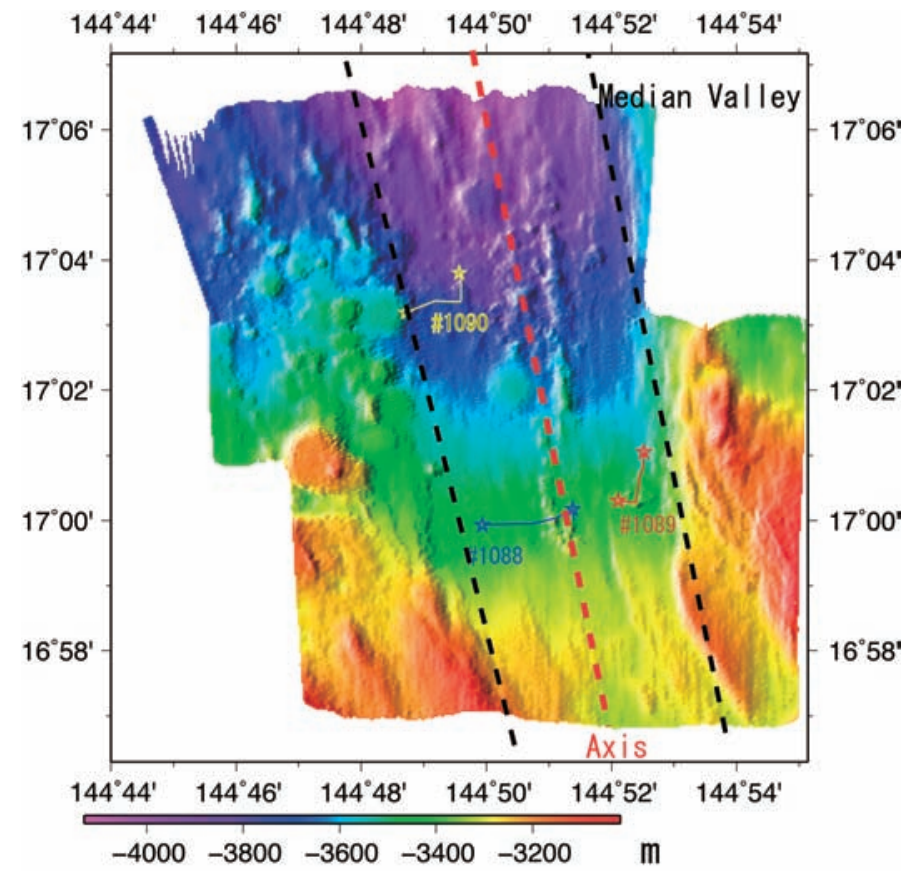

Fig. 4 Bathymetry gridded at $50 \mathrm{~m}$ intervals and three dive tracks on the YK08-08 Leg 1 cruise

The blue, red, and yellow lines show dive tracks, and stars indicate landing and leaving points. Black dotted lines delineate the median valley.

図 4 YK08-08 Leg1航海で行った3潜航の測線と周辺海底地形

50m間隔でグリッドデー夕を作成. 各潜航の測線, 星は離着底ポイントを示す.
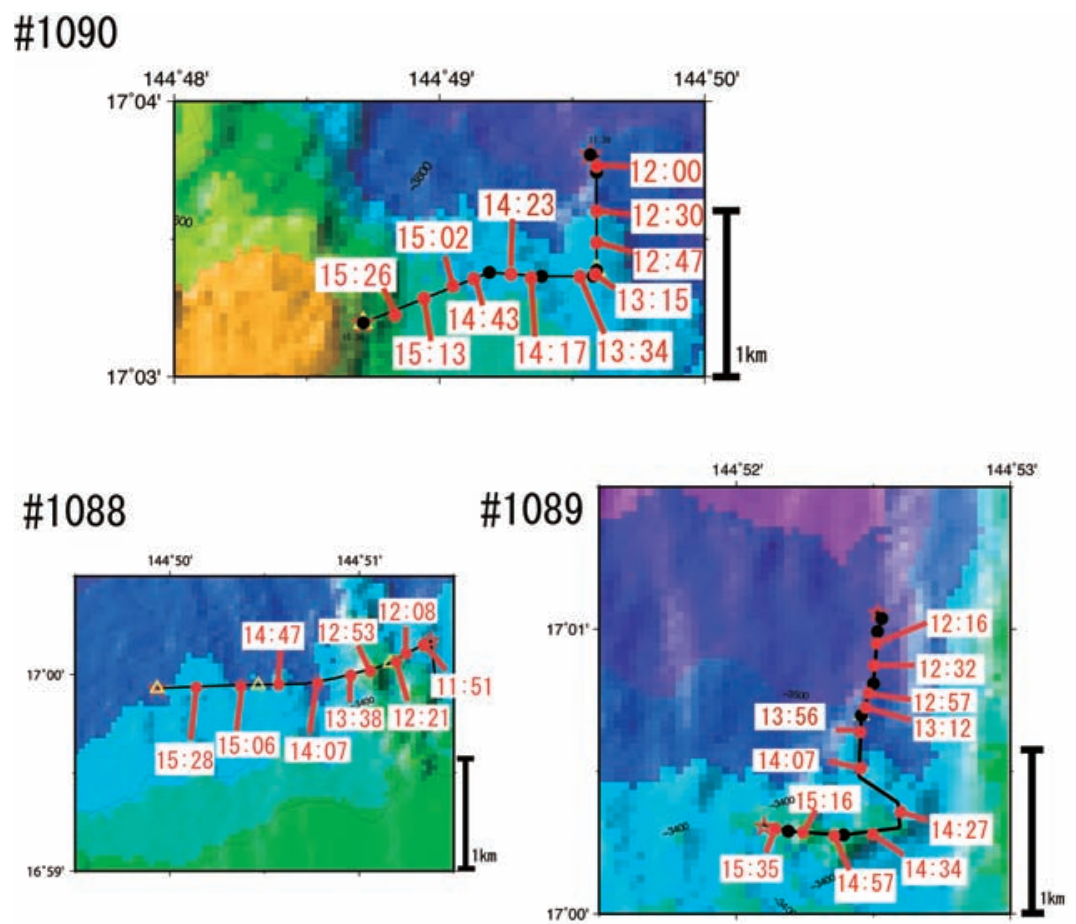

Fig. 5 Each dive track and observation point.

Red numbers indicate observation points of the subbottom profiler's data and time (Guam time) of the seafloor photos. Black circles and yellow triangles indicate rock and sediment sampling points respectively.

図 5 各潜航の測線と解析地点

赤字はサブボトムプロファイラの各データと海底写真の時間を示す (グアム時間)。黒丸は岩石, 黄色三角はプッシュ コアの採取地点を示し，赤星は離着底地点を示す。 
$11: 51$

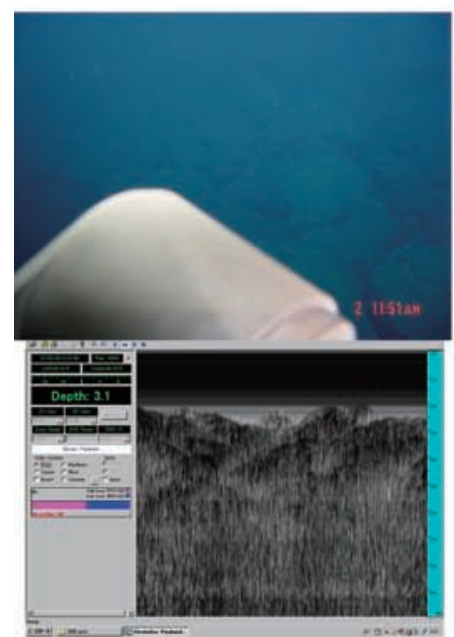

$12: 53$

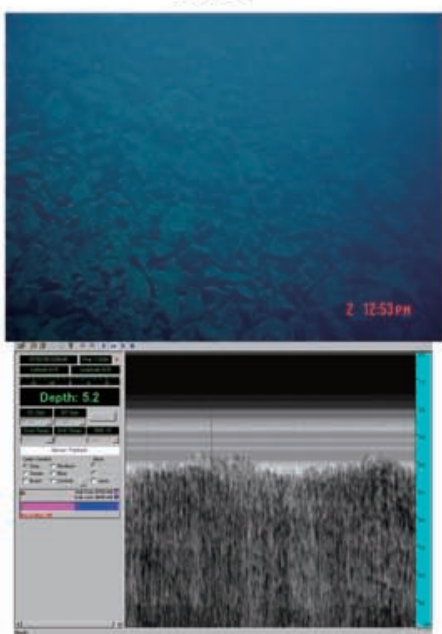

$14: 47$
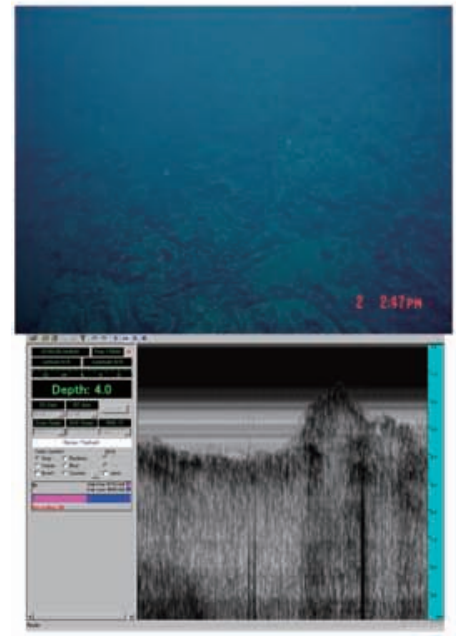

12:08

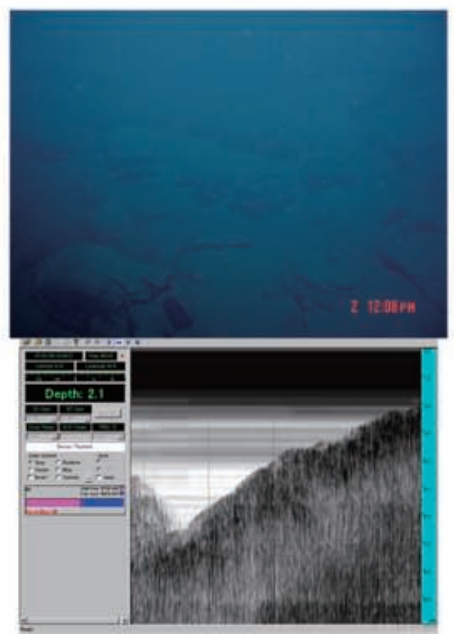

$13: 38$
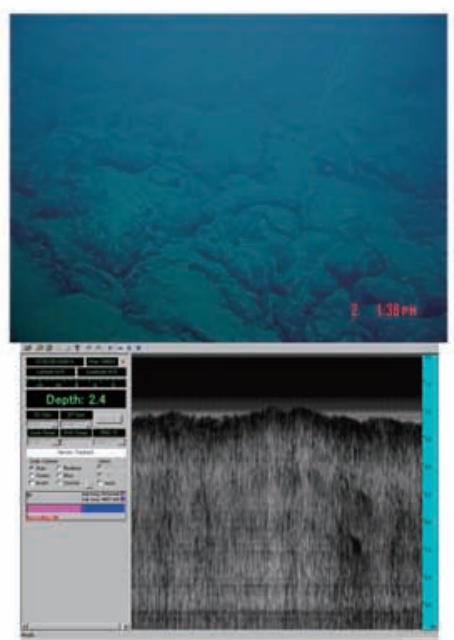

$15: 06$

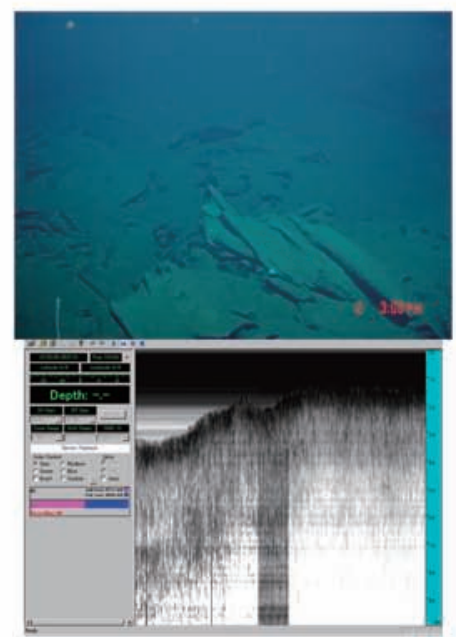

$12: 21$

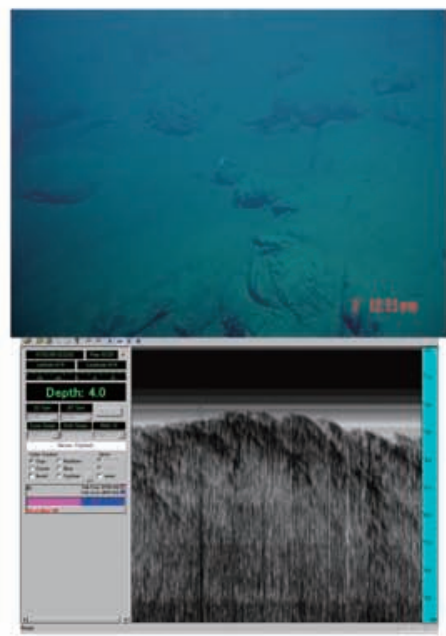

$14: 07$

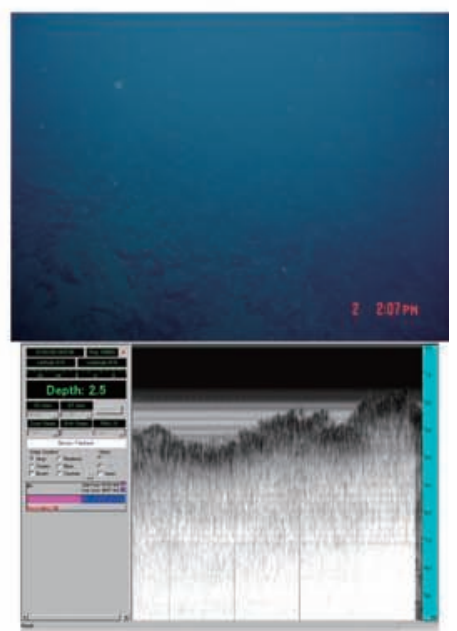

$15: 28$

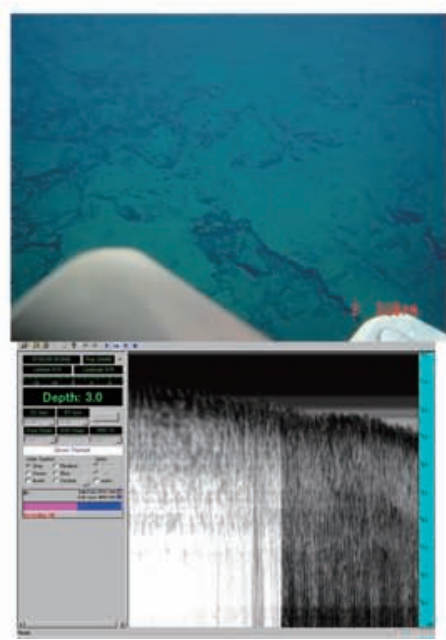

Fig. 6a SBP raw data and outside camera photos on dive \#1088

The numbers indicate time. The times of the outside camera photos and the SBP data correspond to each other.

図 6a Dive\#1088の各時刻のSBP生データと船外カメラ写真

黒字はデー夕の時刻を示しており, 潜水船外側カメラ写真とSBPデータ (Fig.3参照) はそれぞれ同時刻のデー夕に対応している. 
同様の装置，システム（DAI-PACK）を用いた「よこすか」 YK04-07 NIRAI-KANAI Leg1航海での東太平洋海嶺（EPR） off-axis海底溶岩流の観測では，堆積層は $20 \mathrm{~cm} ， 40 \mathrm{~cm}, 1 \mathrm{~m}$ と詳細に識別することができている（Umino, 2004; Kisimoto et al., 2004; Geshi et al., 2007).このように解析の異 なった理由は, SBP観測では層厚と分解能, 底質, 地形に よりデー夕解像度が変化するためと考えられる. マリアナ トラフ拡大軸谷内とEPRのoff-axisの堆積層はともに半遠洋 性堆積物であり, 最厚約 $2 \mathrm{~m}$ 類似している. マリアナト ラフは非常に新しい海底であるため堆積層中に水が多く含 まれ，堆積層が非常に軟らかく，堆積層上面からの反射が 弱い可能性があるが，両海域で最も異なり，大きな影響を 及ぼしているのは地形であることが予想される. EPRは比
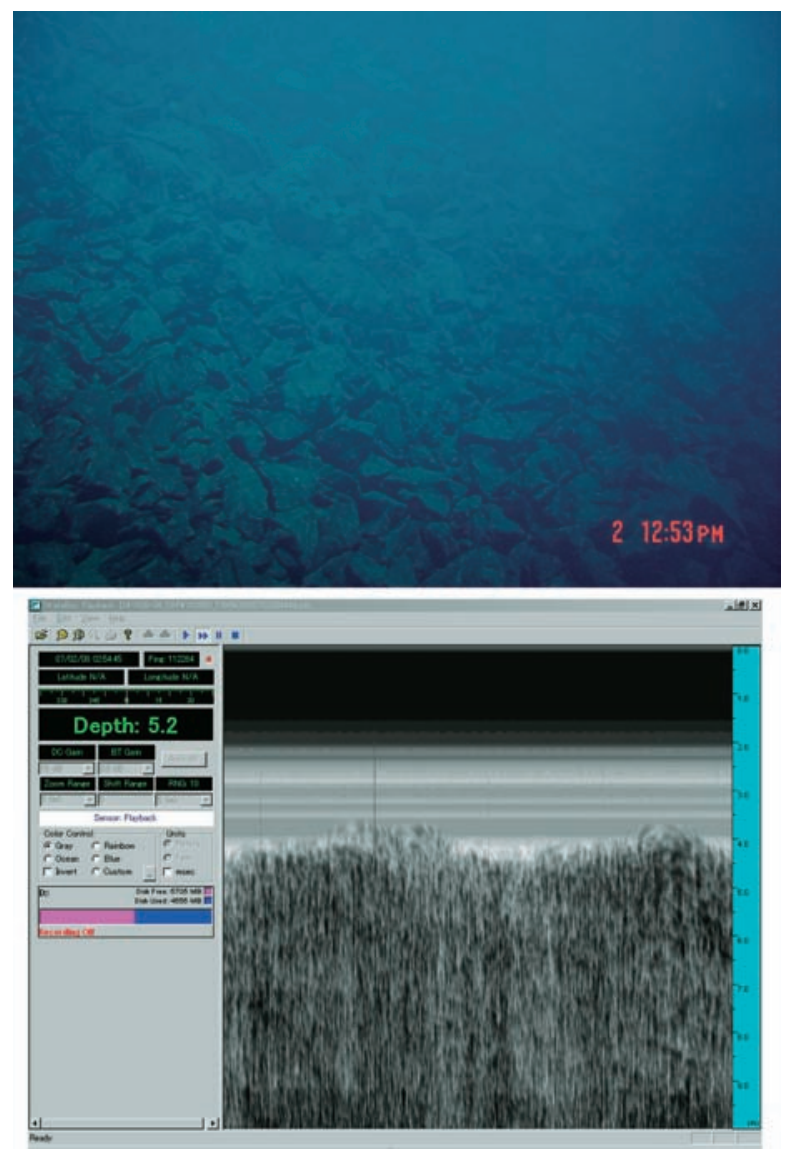

Fig. $6 \mathrm{~b}$ Zoom figure at 12:53 on dive \#1088.

We can find the basement at the seafloor both by visual observation and observation of SBP data, but the SBP data is not clear. This is caused by reflection scattering due to the influence of seafloor topography covered with the brecciated lava flow seen in the photo.

図6b Dive\#1088の12時53分地点拡大図

目視でも基盤が認識でき，SBPデー夕から海底面を識別できるが， 若干ぼやけている.これは写真でみられるような海底の微細地形 の影響と考えられる.
較的平坦な深海斜面を約 12 万年で堆積物が一様に覆う海底 であり, 調査されたoff-axis海底溶岩流は緩やかに噴出し, 形成されたことが考えられる。このことから推測するに EPRの基盤地形はマリアナトラフと比べ，起伏が小さい可 能性がある。一方，マリアナトラフ拡大軸谷内は $0.5 \mathrm{~m} 以 下$ の堆積層がある各地点では, 枕状溶岩, jumbled-wrinkled溶 岩などの起伏の激しい基盤が露出しており, 複雑な微細地 形の, 直下ではないサイドの露岩からの多方面からの強反 射や散乱・回折が重なり合い, 基盤一堆積層境界面が不明 瞭となっているのではないだろうか.これらのことから起 伏の程度により解像度が変化してしまうことが予想され, 議論する際には, 基盤地形の起伏の有無を考慮しなければ ならないと思われる.
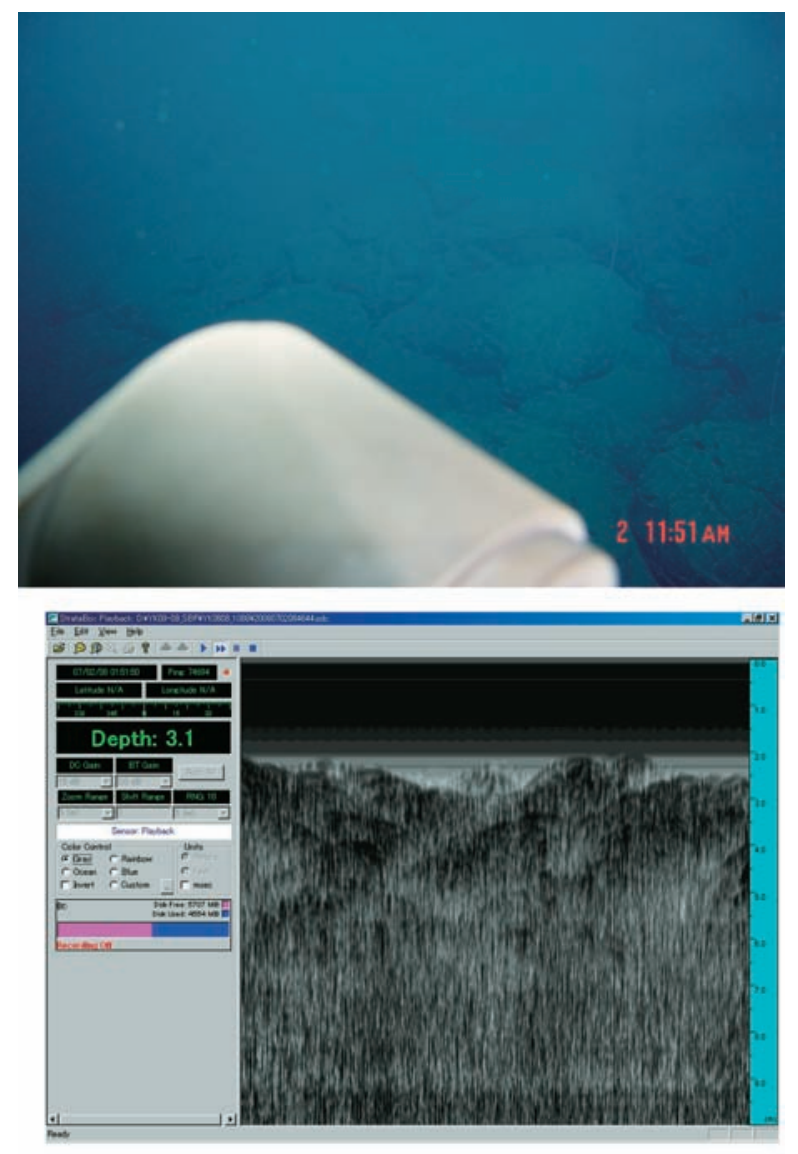

Fig. 6c Zoom figure at 11:51 on dive \#1088.

Although the seafloor is not clear in this photo, the morphology is exposed pillow lavas. SBP data is scattered and diffracted by the rough seafloor.

図 6c Dive\#1088の11時51分地点拡大図 海底の様子が写真からは認識困難である.SBPデー夕は散乱し, 海底面は不明瞭である。 
$12: 16$

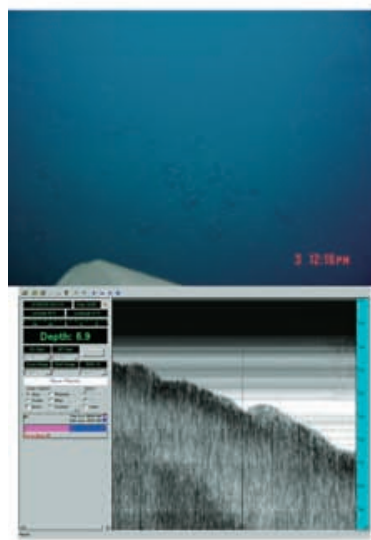

$13: 56$
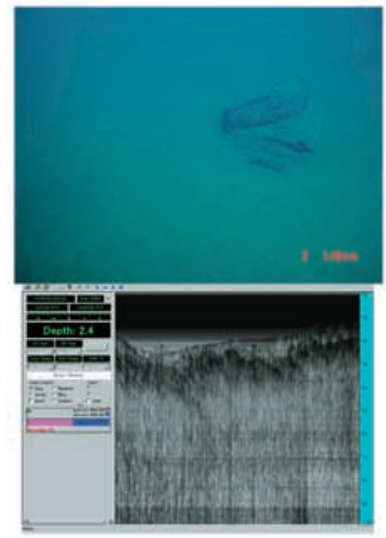

$12: 57$

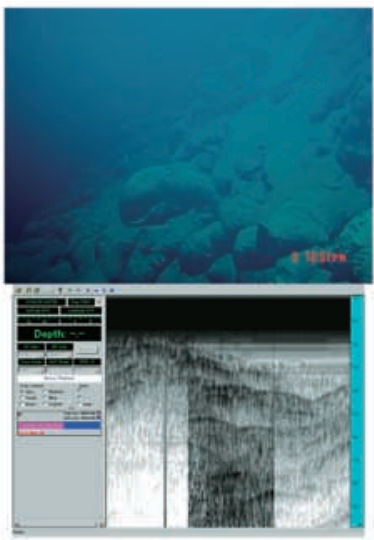

$14: 27$
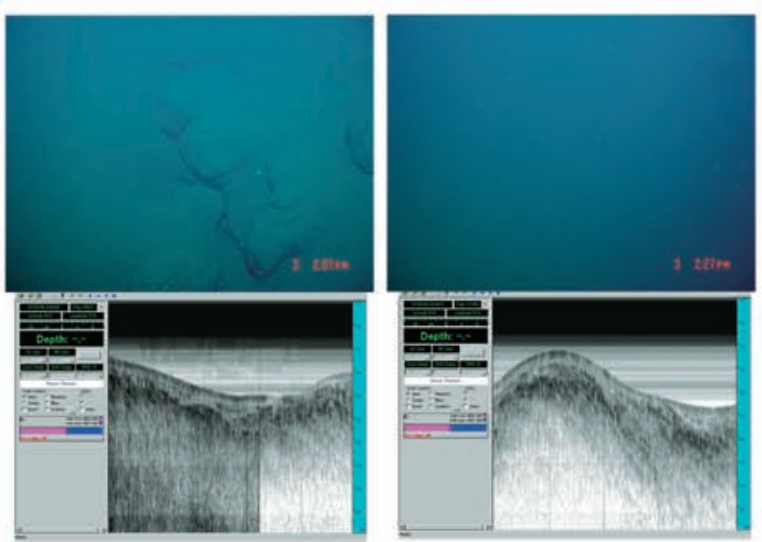

$13: 12$

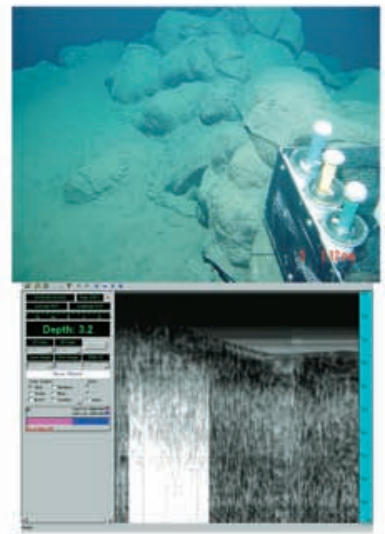

$14: 34$

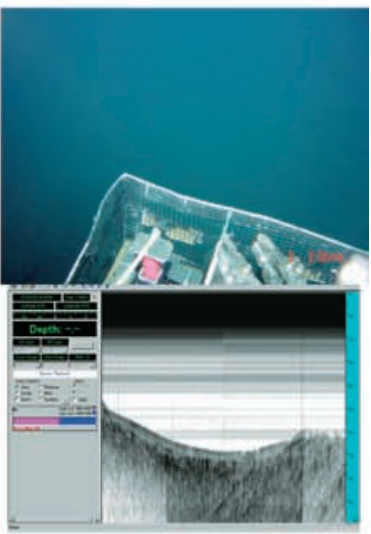

$15: 35$

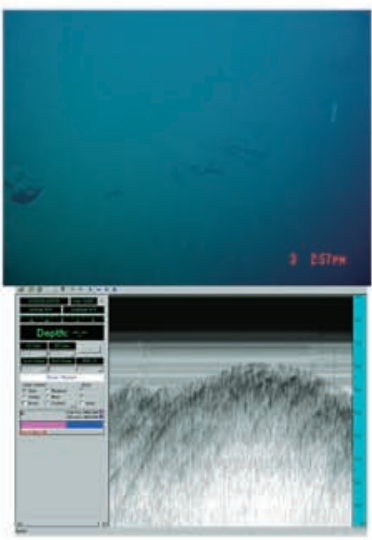

$15: 16$

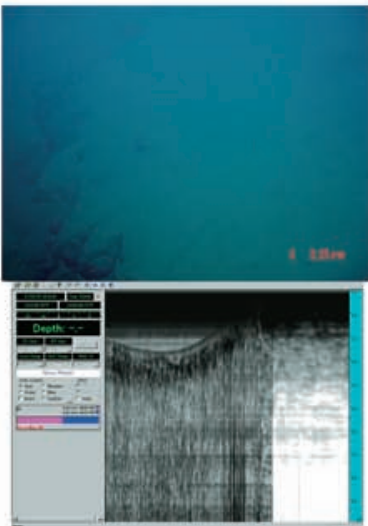

Fig. 7a SBP raw data and outside camera photos on dive \#1089.

The numbers indicate time. The times of the outside camera photos and the SBP data correspond to each other.

図 7a Dive\#10890各時刻のSBP生データと船外カメラ写真

黒字はデータの時刻を示しており，潜水船外側カメラ写真とSBPデータ (Fig.3参照) はそれぞれ同時刻のデータに対応している. 
今後の課題として, 海底付近の観測ではある程度の地 形の起伏の存在は避けられないため, 今後起伏に強い対策 が望まれる.トランスデューサの送受信波に指向性を付け， 多方面からの反射を制限することができればよいだろう か. 潜水船でのSBPトランスデューサ設置場所や設置方法 を変えてみることで, 観測不能ゾーン $2.5 \mathrm{~m}$ 小さくするこ とができるかもしれない。波形をより細かく調べる解析手 法の確立なども課題だろう.

しかしながらSBP観測は，目視観測を補って潜水船観測 の範囲を拡げ，堆積層の定量的な分析から詳細な海底年代 分布の把握，ひいては海洋地殼形成過程の詳細な研究に非 常に大きな効力を発揮するものと思われる. 経験を積んで いくことで, 深海堆積層厚は地球科学に大きく貢献するこ とができると考えられる。
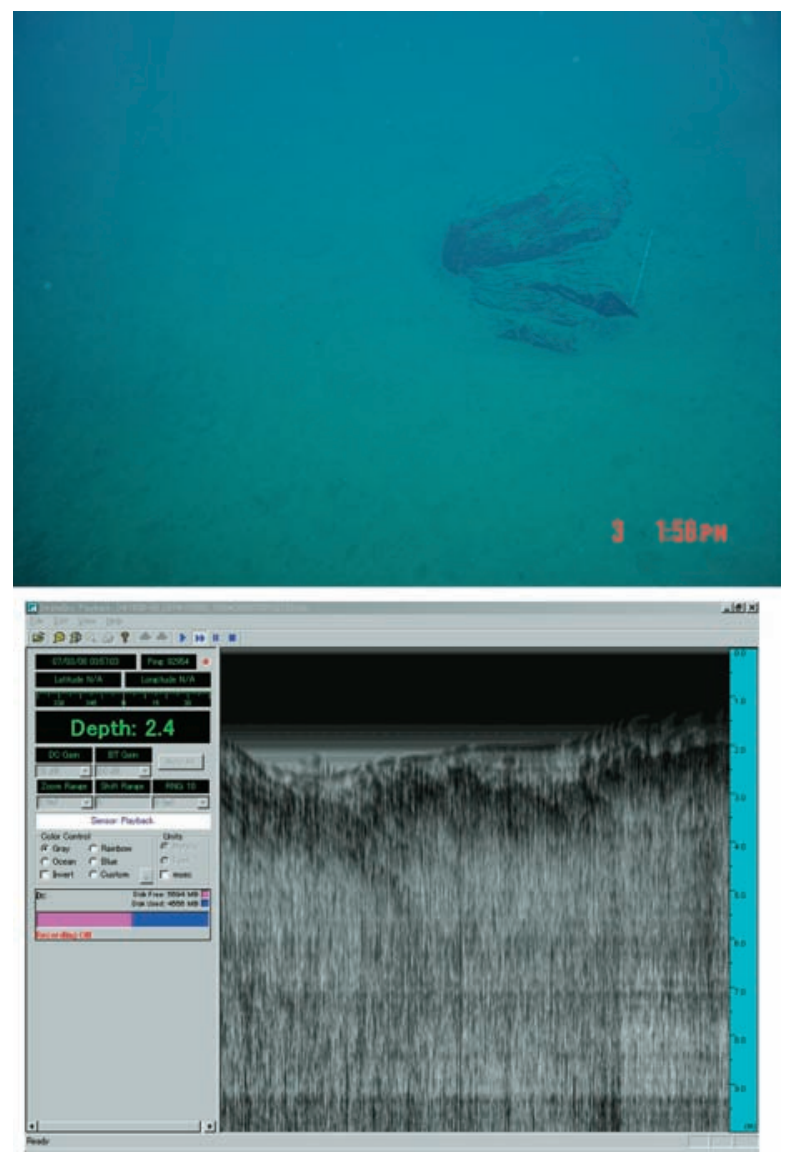

Fig. 7b Zoom figure at 13:56 on dive \#1089.

We can see a heavily sedimented seafloor in the photo. The SBP data indicate a sedimentary layer of $1 \mathrm{~m}$ in thickness. The basement beneath the sedimentary layer has complex topography, seemings to consist of pillowlike lavas.

図 7b Dive\#1089の13時56分地点拡大図

写真で堆積物を認識でき，SBPデータでも識別できる，堆積層厚 は約 $1 \mathrm{~m}$. 基盤面は複雑地形であるようにみえる.

\section{4. まとめ}

調查船「よこすか」YK08-08 Leg.1航海では，有人潜水 調查船「しんかい6500」を用いて，マリアナトラフ背弧拡 大軸 $17^{\circ} \mathrm{N}$ 付近での各潜航\#1088,1089,1090において，岩石・ 堆積物採取と目視観察, 海底地磁気測定, サブボトムプロ ファイラによる堆積層厚測定を行った。サブボトムプロ ファイラのデータと潜水船外写真を照らし合わせ，その地 点での海底の堆積物の有無を観測した。 その結果, 拡大軸 中央から西側斜面に向かった\#1088では，ほぼ堆積層が確 認できなかった。拡大軸東側斜面を調査した\#1089では, 0.5 2mの堆積層が確認できた。拡大軸西側斜面の\#1090は, 表層堆積物が写真では確認できたがSBPデータには反映さ れなかった。本潜航では, サンプリングポイントでのデー 夕の欠如，サンプリングに重点をおいた観測環境であった
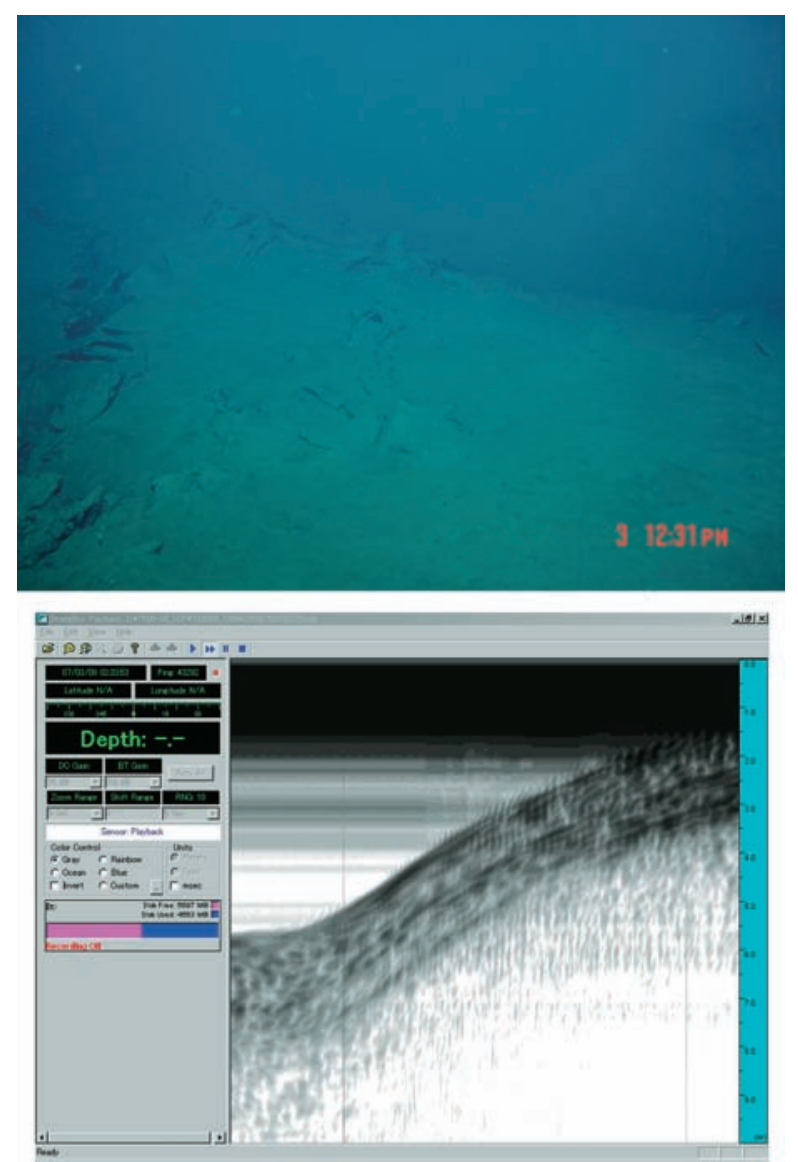

Fig. 7c Zoom figure at 12:32 on dive \#1089.

The sedimentation is obvious both in the photo and in the SBP data. The sedimentary layer has a double-layered structure. The sediment thickness of the layer is $2 \mathrm{~m}$.

図 7c Dive\#1089012時32分地点拡大図

写真, SBPデータともに堆積層がみられる。堆積層が2重になって いる. 堆積層厚は約 $2 \mathrm{~m}$. 


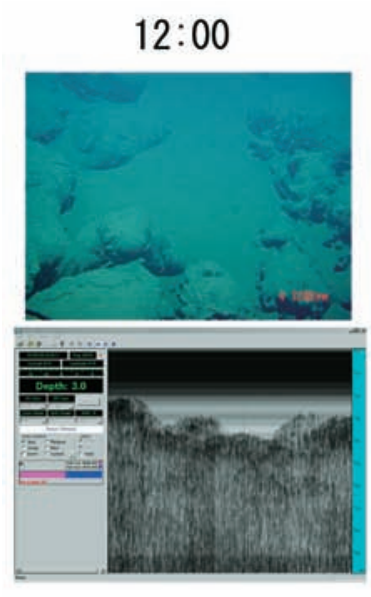

$13: 15$

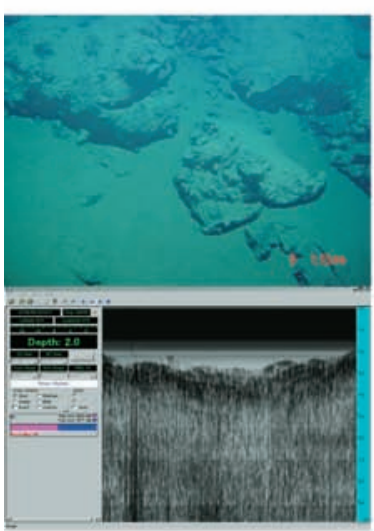

$14: 48$
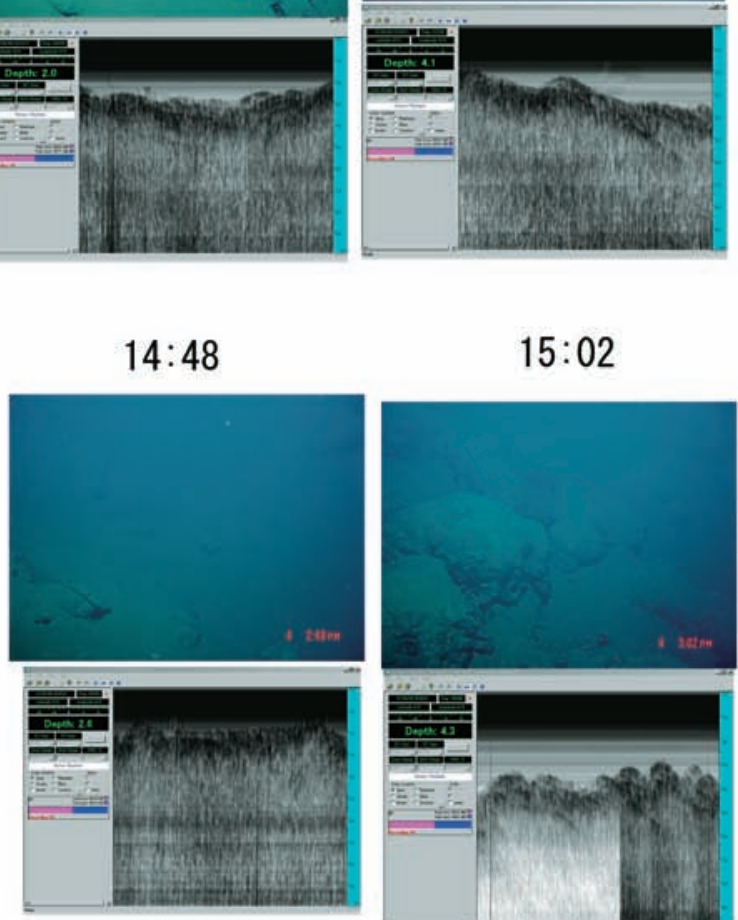

$15: 02$
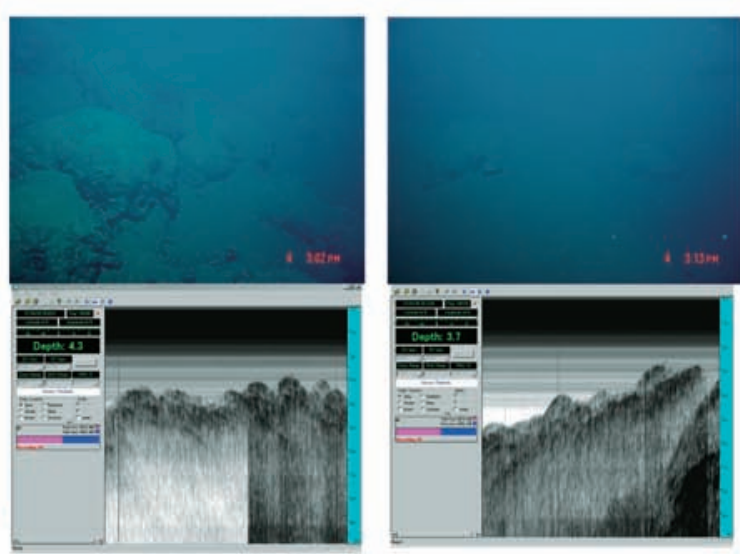

$14: 17$
$12: 47$
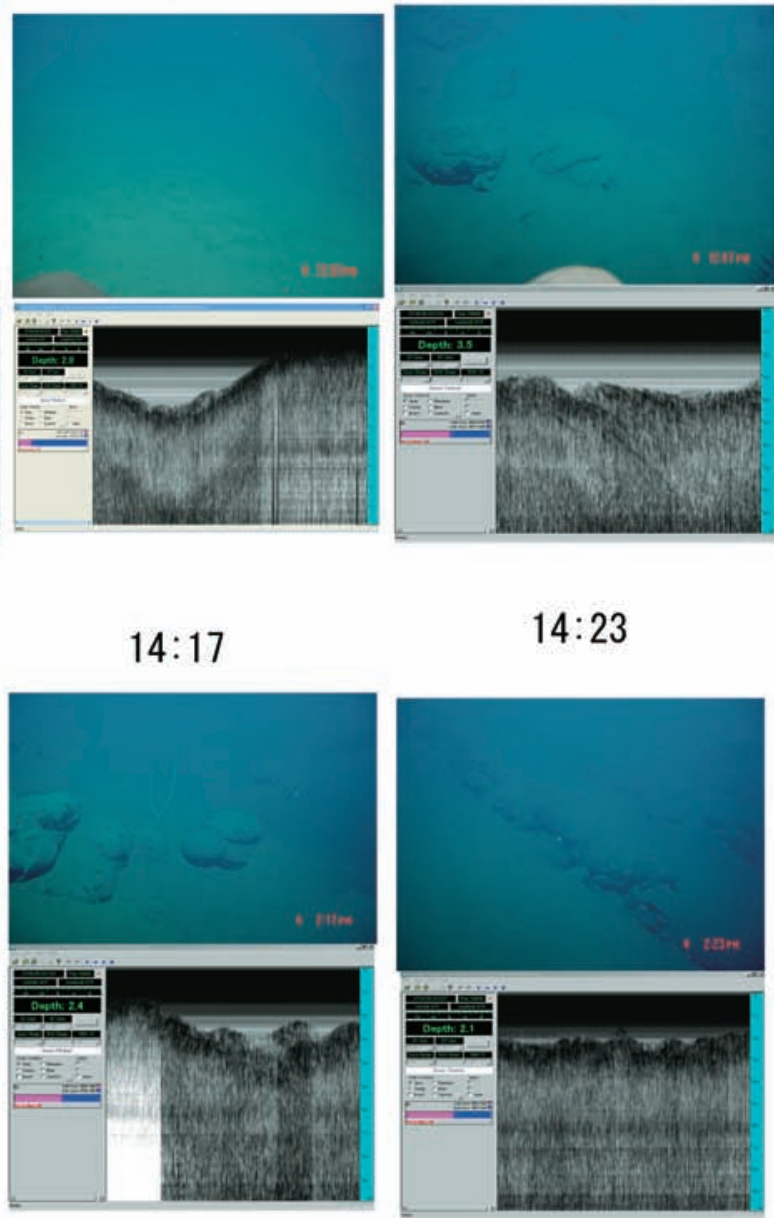

$15: 26$

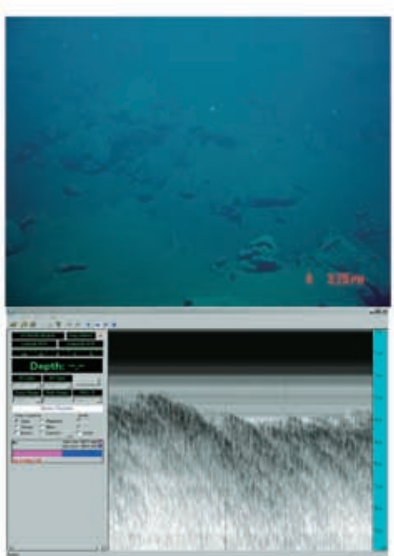

Fig. 8a SBP raw data and outside camera photos on dive \#1090.

The numbers indicate time. The times of the outside camera photos and the SBP data correspond to each other.

困 8a Dive\#1090の各時刻のSBP生データと船外カメラ写真

黒字はデータの時刻を示しており, 潜水船外側カメラ写真とSBPデータ（Fig.3参照）はそれぞれ同時刻のデータに対応している. 
Table. 2. Observation of sediment using SBP data and photos on each dive.

This chart indicates existence or nonexistence of sediment from observation of SBP data and visual observations. If the sedimentary layer thickness can be estimated, the value is shown. Symbols indicate: $\bigcirc$ :sediment found $\triangle$ : sediment found but unclear $\times$ : sediment not found

\title{
表2 各潜航のSBP と写真による表層堆積物の有無
}

SBPと船外写真で観察できた表層堆積物の有無を示す.SBPデータから堆積層厚を推定できた場合は数値を示す.

\begin{abstract}
○：確認できる $\triangle$ : わずかに堆積物が確認できる $\times$ : 確認できない
\end{abstract}

1)\#1088
\begin{tabular}{|c|c|c|}
\hline Time(hh:mm) & SBP $(\mathrm{m})$ & Photo \\
\hline $11: 51$ & $\times$ & $\times$ \\
\hline $12: 08$ & $\times$ & $\Delta$ \\
\hline $12: 21$ & $\times$ & $\Delta$ \\
\hline $12: 53$ & $\times$ & $\times$ \\
\hline $13: 38$ & $\times$ & $\times$ \\
\hline $14: 07$ & $\times$ & $\times$ \\
\hline $14: 47$ & $\times$ & $\times$ \\
\hline $15: 06$ & $\times$ & $\Delta$ \\
\hline $15: 28$ & $\times$ & $\times$ \\
\hline
\end{tabular}

2) \#1089
\begin{tabular}{|c|c|c|}
\hline Time(hh:mm) & SBP(m) & Photo \\
\hline $12: 16$ & $\times$ & $\Delta$ \\
\hline $12: 32$ & 2 & $O$ \\
\hline $12: 57$ & $\times$ & $\Delta$ \\
\hline $13: 12$ & 0.5 & $\bigcirc$ \\
\hline $13: 56$ & 1 & $\bigcirc$ \\
\hline $14: 07$ & 1 & $O$ \\
\hline $14: 27$ & 1 & $O$ \\
\hline $14: 34$ & 0.5 & $\bigcirc$ \\
\hline $14: 57$ & $\Delta$ & $O$ \\
\hline $15: 16$ & $\times$ & $\times$ \\
\hline $15: 35$ & 0.5 & $\bigcirc$ \\
\hline
\end{tabular}

3) \#1090

\begin{tabular}{|c|l|l|}
\hline Time(hh:mm) & SBP(m) & Photo \\
\hline $12: 00$ & $\times$ & $\Delta$ \\
\hline $12: 30$ & $\times$ & $\Delta$ \\
\hline $12: 33$ & $\times$ & $O$ \\
\hline $12: 47$ & $\times$ & $\Delta$ \\
\hline $13: 15$ & $\times$ & $\Delta$ \\
\hline $13: 34$ & $\times$ & $\Delta$ \\
\hline $14: 17$ & $\times$ & $\Delta$ \\
\hline $14: 23$ & $\times$ & $\Delta$ \\
\hline $14: 48$ & $\times$ & $\Delta$ \\
\hline $15: 02$ & $X$ & $\Delta$ \\
\hline $15: 13$ & $X$ & $O$ \\
\hline $15: 26$ & $X$ & $\Delta$ \\
\hline & & \multicolumn{2}{|l}{} \\
\hline
\end{tabular}
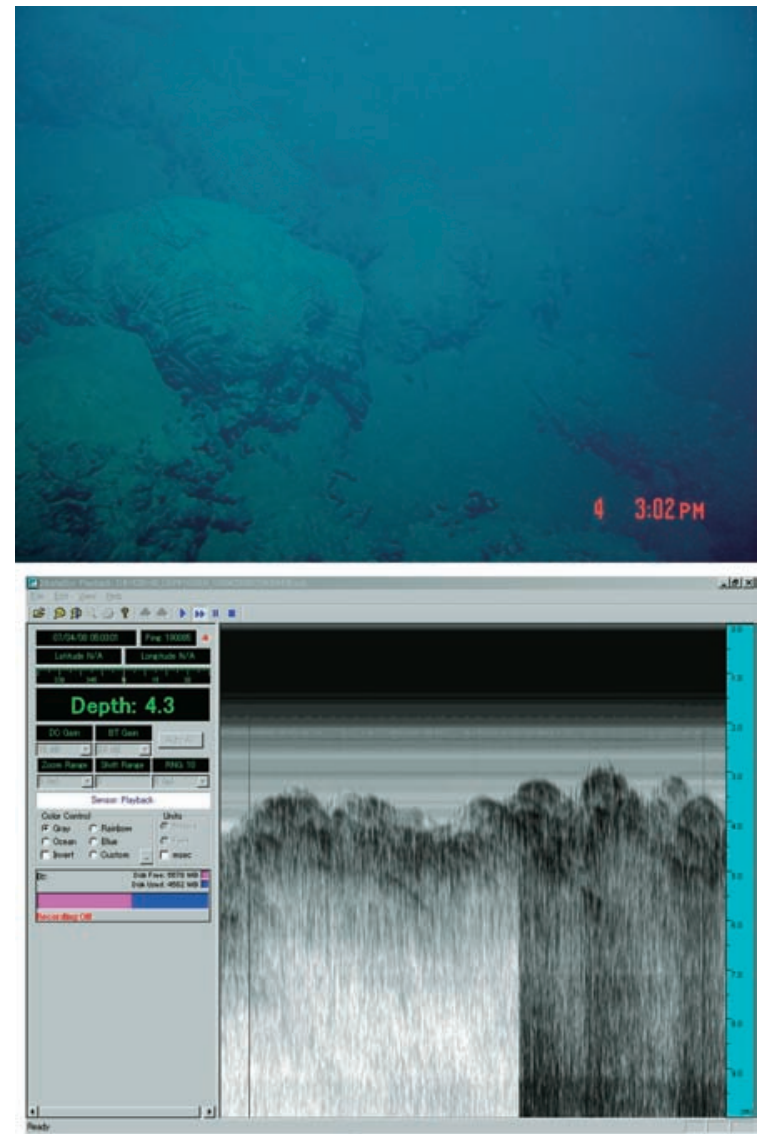

Fig. 8b Zoom figure at 15:02 on dive \#1090.

Although the seafloor is not clear in this photo, the morphology is exposed pillow lavas. SBP data are scattered and diffracted by the rough seafloor.

図 8b Dive\#1090015時02分地点拡大図

SBPデータが散乱し，海底面が不明暸である。堆積厚も識別でき なかった。
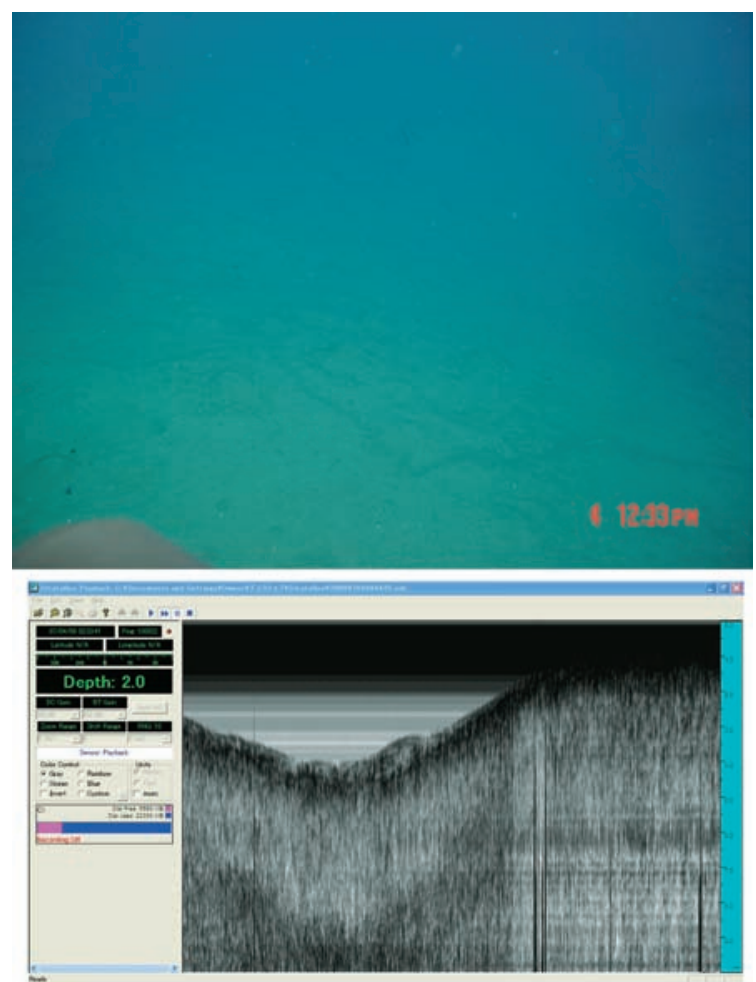

Fig. 8c Zoom figure at 12:33 on dive \#1090.

The seafloor seems to be covered with thick sediment in the photo, but the thickness of the sedimentary layer is unclear in the SBP data. Its thickness is probably too thin to be identified.

図 8c Dive\#1090012時33分地点拡大図

写真では堆積物を認識できるが，SBPデータから堆積層を識別す ることはできなかった. 
ことを除き, 表層堆積層が明瞭ではなかった主な原因は, 堆積層の厚さと地形による影響である。本海域は，新しい 海底であるため堆積層が薄く, 軟らかいことが考えられ, 起伏が大きい地形が広く分布するために起こる多方面反射 により識別が困難であったと考えられる，それでも，試料 サンプリングが主な目的である3潜航から得られたSBP データから堆積層厚が識別でき，溶岩流の新旧を判別でき たことはマリアナトラフ背弧拡大軸の溶岩噴出率の局所的 な変化を解明する助力となると考えられる.

これら3潜航を行った海底は，潜航調査の測線の範囲内 では，\#1089，\#1090，\#1088の順に形成された可能性があ る. 堆積速度を $2 \mathrm{~cm} / \mathrm{kyr}$ と仮定すれば，0.5〜 2mの堆積層 厚を識別できた\#1089周辺の溶岩流は約10万年前に形成さ れ，0.5m以下の堆積層厚であった\#1090は約 $2.5 万$ 年前に形 成，堆積層を認識できなかった地点が多かった＃1088は
2.5 万年前より新しく形成されたことが推定される. また, \#1089の観測では，堆積層厚は2重堆積構造をした地点もみ られ，今後コアリングなどの詳細な調査により海底での噴 火イベントの存在を明らかにできるかもしれない.

\section{謝辞}

調査航海を通じて，「よこすか」乗組員や「しんかい 6500」運航チーム，日本海洋事業の観測技術員には，調査 航海を実施にあたり，多大なる支援をいただいた。岸本清 行博士ならびに匿名の査読者には，論文を改良する有益な コメントをいただいた。本研究には，科学研究費補助金・ 基盤研究（C）（代表：富士原敏也, 課題番号：20540417), 独立行政法人海洋研究開発機構地球内部変動研究センター 運営交付金の一部を使用した。

\section{\#1090}

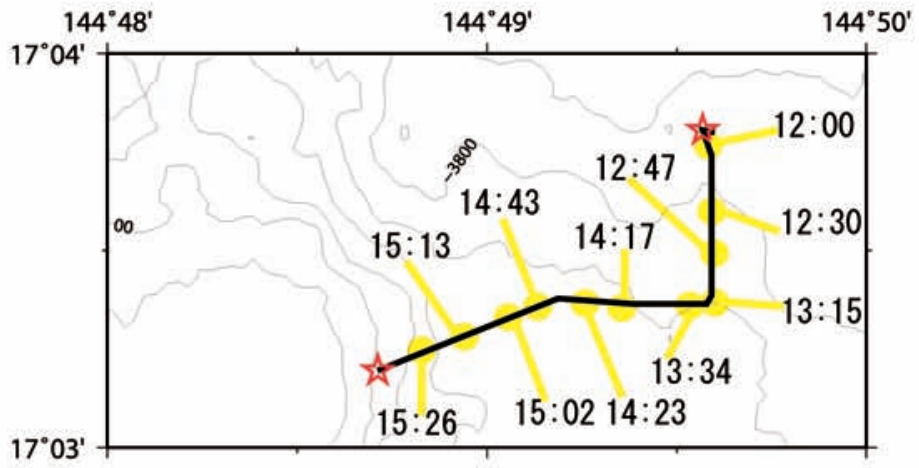

\section{$\# 1088$}

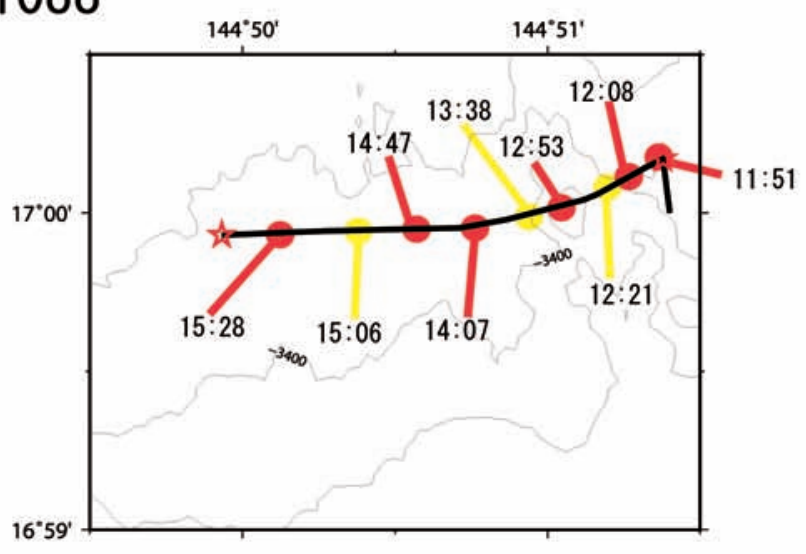

\section{\#1089}

Fig. 9 Sedimentary layer distribution on each dive

Red circle: Sedimentary layer cannot be found; yellow circle: sedimentary layer cannot be determined from SBP data, but can be found in photos; green circle: sedimentary layer thickness is about $0.5 \mathrm{~m}$; blue circle: sedimentary layer thickness is more than $1 \mathrm{~m}$; red stars: landing and leaving points.

図 9 各潜航の堆積層厚分布

赤：堆積層を確認できない 黄：SBPでは確認できないが，写真では確認できる 緑：約 $0.5 \mathrm{~m}$ 青：1m以上 赤星：離着底地点 


\section{参考文献}

Asada, M., A. Deschamps, T. Fujiwara, and Y. Nakamura (2007), Submarine lava flow emplacement and faulting in the axial valley of two morphologically distinct spreading segments of the Mariana back-arc basin from Wadatsumi side-scan sonar image, Geochem. Geophys. Geosyst., 8(4), Q04001, 10.1029/2006GC001418.

Deschamps, A., T. Fujiwara, M. Asada, L. Montési, and P.Gente(2005), Faulting and volcanism in the axial valley of the slow spreading center of the Mariana back-arc basin from Wadatsumi side-scan sonar images, Geochem. Geophys. Geosyst., 6(5), Q05006, 10.1029/2004GC000881.

Fujiwara, T., S. Umino, M. Asada, Y. Koike, T. Kanamatsu, K.Kimoto and S. Okada(2008), A submersible study of the Mariana Trough back-arc spreading center at $17^{\circ} \mathrm{N}$, JAMSTEC Rep. Res. Dev., 8, 61-73.

Geshi,N, S. Umino, H.Kumagai, J.M.Sinton, S.M.White, K.Kishimoto, and T.M.Hilde(2007), Discrete plumbing systems and heterogeneous magma sources of a $24 \mathrm{~km}^{3}$ off-axis lava field on the western flank of East Pacific Rise, $14^{\circ} \mathrm{S}$, Earth Planet. Sci. Lett. 258, 61-72.
Kisimoto, K., S. Umino, N. Geshi, T. W. Hilde, H. Kumagai, J. Sinton, and S. M. White(2004), Largest off-axis lava flow field from the southern East Pacific Rise at $14^{\circ} \mathrm{N}$, :Preliminary, results of the NIRAI-KANAI cruise leg, YK04-07 "Yokosuka /Shinkai Shinkai 6500” dives, AGU, 85(47), Fall Meet. Suppl., abstract V53A-0612.

Kumagai, H., ed.(2005), Preliminary cruise report YK0516 Leg 1 "Yokosuka/Shinkai 6500” URANIWA expedition.

Takahashi, N., S. Kodaira, S. L. Klemperer, Y. Tatsumi, Y. Kaneda, and K. Suyehiro(2007), Crustal structure and evolution of the Mariana intra-oceanic island arc, Geology. 35, 203-206.

Takahashi, N., S. Kodaira, Y. Tatsumi, Y. Kaneda, and K. Suyehiro(2008), Structure and growth of the Izu-Bonin-Mariana arc crust: 1 . Seismic constraint on crust and mantle structure of the Mariana arc-back-arc system, J. Geophys. Res., 113, B01104, doi:10.1029/2007JB005120.

Umino, S., ed.(2004), Preliminary report YK04-07 "Yokosuka/Shinkai 6500" NIRAI-KANAI 1, Geological and petrological study of large off-axis lava fields along the southern East Pacific Rise at $8^{\circ} \mathrm{S}-19^{\circ} \mathrm{S}$ 